\title{
ON THE ACTION OF CERTAIN SALTS ON PHAGO- CYTOSIS AND VIRULENCE OF STREPTOCOCCI
}

\author{
TORASABURO OTSUBO
}

From the John McCormick Institute for Infectious Diseases, Chicago

That certain salts in about the same concentration as physiologic salt solution may inhibit phagocytosis in vitro was demonstrated by Hektoen and Ruediger, ${ }^{1}$ who found that $\mathrm{CaCl}_{2}, \mathrm{BaCl}_{2}, \mathrm{SrCl}_{2}, \mathrm{MgCl}_{2}$, $\mathrm{K}_{2} \mathrm{SO}_{4}, \mathrm{NaHCO}_{3}, \quad \mathrm{Na}_{3} \mathrm{C}_{6} \mathrm{H}_{5} \mathrm{O}_{7}, \mathrm{Na}_{2} \mathrm{C}_{2} \mathrm{O}_{4}, \mathrm{~K}_{4} \mathrm{Fe}(\mathrm{CN})_{6}$, neutralized opsonin in such a way that it did not act on bacteria.

Hamburger and his associates ${ }^{2}$ found that highly diluted solutions of $\mathrm{BaCl}_{2}$ and $\mathrm{SrCl}_{2}$ did not stimulate phagocytosis, while $\mathrm{MgCl}_{2}$ and $\mathrm{CaCl}_{2}$ had distinctly stimulating effects, especially the latter salt. They studied the phagocytosis of particles of carbon. Eggers ${ }^{3}$ observed that $\mathrm{BaCl}_{2}$ and $\mathrm{NaF}$ are toxic for leukocytes, while $\mathrm{MgCl}_{2}$ stimulates phagocytic activity of leukocytes. Neisser and Guerinni ${ }^{4}$ found that a large amount of KI may inhibit phagocytosis and a small amount increase phagocytic activity. Otanni noted that when sodium citrate was added to the blood of tuberculous patients to the extent of $1 \%$ the phagocytic action became stronger than that of normal human blood, and Otanni and Shiiba obtained similar results in typhoid fever. ${ }^{5}$ Shiiba demonstrated that in the case of normal blood sodium citrate may neutralize opsonin; hence, in the case of the blood of a typhoid patient the conditions must be different. Maganatsu ${ }^{6}$ noted that a $1 \%$ solution of $\mathrm{CaCl}_{2}$ increases phagocytosis under the influence of immune serum against certain blood corpuscles, but $\mathrm{KI}$ in $1 \%$ solution has no such effect. Nagai and Ito ${ }^{7}$ found that $0.01-0.005 \%$ solution of $\mathrm{CaCl}_{2}$ given by mouth stimulated the leukocytes of tuberculous patients, but had no effect on the serum.

We see from these reports that different results have been obtained by investigators studying the action of the same salt on phagocytosis. As phagocytosis probably is the most important factor in resistance to streptococcus infection, I undertook to study the influence of different salts on the phagocytosis of streptococci both inside and outside the animal body. In the test tube experiments I used normal rabbit serum and the leukocytes of normal guinea-pig, well washed. The experiments in vivo were made in the peritoneal cavity of the mouse, guinea-pig and rabbit. I observed that 3 hours after the

1 Jour. Infect. Dis., 1905, 2, p. 135.

2 Biochem. Ztschr., 1908, 9, p. 295; 1909, 24, p. 470.

3 Jour. Infect. Dis., 1909, 6, p. 667.

4 Matsushita, Parasit. Krankh., 1916, 4, p. 169.

5 Saikingaku. Zasshi, 1917, 1918, 1919, 1920.

- Nippon Biseibutsu Gakkai Zasshi, 1918, 6, p. 617.

7 Nippon Eiseibutusu Gakkai Zasshi, 1920, 12, p. 235. 
injection of streptococci into the peritoneal cavity a sufficient number of polymorphonuclear neutrophiles had migrated into the cavity for experiments on phagocytosis; hence, in all my experiments, the peritoneal fluid was examined 3 hours after the injection of streptococci. I used $\mathrm{M} / 8$ solutions of various salts, diluting when necessary with normal salt solution, and a typically hemolytic streptococcus isolated from the frontal sinus and cultivated artificially for about 2 years. The preparations were stained with Wright's method.

A mixture consisting of $0.5 \mathrm{cc}$ of M/8 solution of salt, $0.5 \mathrm{cc}$ of normal salt solution and $0.5 \mathrm{cc}$ of a 24 -hour growth of this streptococcus in plain broth was injected into the peritoneal cavity of the mouse. After 3 hours peritoneal fluid was withdrawn, preparations were made and the number of leukocytes engaged in phagocytosis, as well as the average number of streptococci taken up by each phagocytic leukocyte, was determined. Two sets of experiments were made, one with a nonvirulent strain of the streptococcus, a strain that had not been passed through animals, and a virulent strain obtained by passage through 6 to 8 mice in succession. The results are given in table 1 , and they show that the various salts used inhibited phagocytosis of streptococci in the peritoneal cavity of the mouse. It is also shown that there is much less phagocytosis in the case of the virulent as compared with nonvirulent strain, which is in full accord with results of previous observation, notably those by Denys and Marschand, Neufeld and Hune, Hektoen ${ }^{8}$ and others.

Further experiments, the results of which are given in tables 2 and 3 , were made in the same way with higher dilution of the same salts.

Observations were also made on the phagocytosis of streptococci in vitro in mixtures of normal rabbit serum, normal guinea-pig leukocytes and different salt solutions, equal quantities. These mixtures were incubated at $37 \mathrm{C}$. for one hour when smears were made (table 3 ), the results showing that higher dilutions of the salts used have no stimulating effect on phagocytosis, there being simply a diminution of the inhibitory power that lower dilutions exercise.

In the next experiment, guinea-pigs were injected subcutaneously with $3 \mathrm{cc}$ of salt solution once a day for 5 days. After the last injection a suspension of avirulent streptococci was injected into the peritoneal cavity, preparations of the peritoneal fluid made 3 hours later and the degree of phagocytosis determined as before (table 4). 
TABLE 1

Influence of M/8 Salt Solutions on Phagocytosis in the Peritoneal Cavity of the Mouse

\begin{tabular}{|c|c|c|c|c|}
\hline \multirow[b]{2}{*}{ Salts } & \multicolumn{2}{|c|}{ Nonvirulent Streptococei } & \multicolumn{2}{|c|}{ Virulent Streptococel } \\
\hline & $\begin{array}{c}\text { Average } \\
\text { Number of } \\
\text { Cocei in Each } \\
\text { Leukocyte }\end{array}$ & $\begin{array}{l}\text { Percentage } \\
\text { of } \\
\text { Phagocytic } \\
\text { Leukocytes }\end{array}$ & $\begin{array}{c}\text { Average } \\
\text { Number of } \\
\text { Cocei in Each } \\
\text { Leukocyte }\end{array}$ & $\begin{array}{c}\text { Percentage } \\
\text { of } \\
\text { Phagocytic } \\
\text { Leukocytes }\end{array}$ \\
\hline 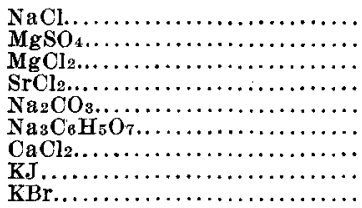 & $\begin{array}{l}6.24 \\
1.428 \\
1.081 \\
0.975 \\
0.990 \\
0.840 \\
0.916 \\
2.480 \\
3.450\end{array}$ & $\begin{array}{l}78 \\
51 \\
47 \\
39 \\
45 \\
42 \\
39 \\
62 \\
69\end{array}$ & $\begin{array}{l}0.62 \\
0.24 \\
0.25 \\
0.22 \\
0.20 \\
0.22 \\
0.21 \\
0.32 \\
0.35\end{array}$ & $\begin{array}{l}24 \\
16 \\
15 \\
13 \\
12 \\
15 \\
14 \\
17 \\
18\end{array}$ \\
\hline
\end{tabular}

TABLE 2

Influence of M/100 and M/300 Salt Solutions on Phagocytosis in the Peritoneal Cavity of the Mouse

\begin{tabular}{|c|c|c|c|c|}
\hline \multirow[b]{2}{*}{ Salts } & \multicolumn{2}{|c|}{ M/100 Solutions } & \multicolumn{2}{|c|}{ M/300 Solutions } \\
\hline & $\begin{array}{c}\text { Average } \\
\text { Number of } \\
\text { Cocci in Each } \\
\text { Leukocyte }\end{array}$ & $\begin{array}{c}\text { Percentage } \\
\text { of } \\
\text { Phagocytic } \\
\text { Leukocytes }\end{array}$ & $\begin{array}{c}\text { Average } \\
\text { Number of } \\
\text { Cocci in Each } \\
\text { Leukocyte }\end{array}$ & $\begin{array}{c}\text { Percentage } \\
\text { of } \\
\text { Phagocytic } \\
\text { Leukocytes }\end{array}$ \\
\hline 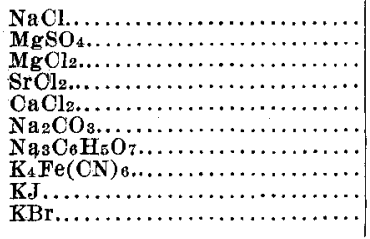 & $\begin{array}{r}12.5 \\
9.2 \\
8.8 \\
10.5 \\
10.7 \\
9.5 \\
9.1 \\
7.3 \\
10.7 \\
12.0\end{array}$ & $\begin{array}{l}73 \\
60 \\
60 \\
65 \\
63 \\
55 \\
62 \\
52 \\
69 \\
70\end{array}$ & $\begin{array}{l}14.3 \\
13.8 \\
12.0 \\
12.8 \\
14.5 \\
12.5 \\
13.0 \\
10.0 \\
12.2 \\
12.0\end{array}$ & $\begin{array}{l}86 \\
85 \\
83 \\
86 \\
83 \\
81 \\
78 \\
75 \\
75 \\
79\end{array}$ \\
\hline
\end{tabular}

TABLE 3

Influence of Dilute Salt Solutions on Phagocytosis in Vitro

\begin{tabular}{|c|c|c|c|c|}
\hline \multirow[b]{2}{*}{ Salts } & \multicolumn{2}{|c|}{ M/50 Solutions } & \multicolumn{2}{|c|}{ M/200 Solutions } \\
\hline & $\begin{array}{c}\text { Average } \\
\text { Number of } \\
\text { Cocci in Each } \\
\text { Leukocyte }\end{array}$ & $\begin{array}{c}\text { Percentage } \\
\text { of } \\
\text { Phagocytic } \\
\text { Leukocytes }\end{array}$ & $\begin{array}{c}\text { Average } \\
\text { Number of } \\
\text { Cocci in Each } \\
\text { Leukocyte }\end{array}$ & $\begin{array}{c}\text { Percentage } \\
\text { of } \\
\text { Phagocytic } \\
\text { Leukocytes }\end{array}$ \\
\hline 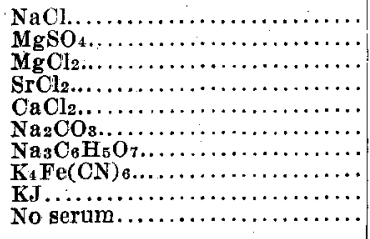 & $\begin{array}{l}6.4 \\
5.5 \\
5.8 \\
6.1 \\
4.5 \\
6.0 \\
5.5 \\
3.5 \\
5.8 \\
1.3\end{array}$ & $\begin{array}{l}71 \\
65 \\
57 \\
69 \\
55 \\
64 \\
64 \\
43 \\
64 \\
19\end{array}$ & $\begin{array}{l}7.8 \\
6.5 \\
6.5 \\
6.3 \\
6.7 \\
6.0 \\
6.0 \\
6.1 \\
6.8 \\
1.3\end{array}$ & $\begin{array}{l}70 \\
60 \\
62 \\
60 \\
62 \\
55 \\
60 \\
58 \\
67 \\
15\end{array}$ \\
\hline
\end{tabular}

8 Jour. Am. Med. Assn., 1906, 46, p. 1407. 
TABLE 4

The Influence of Injections of Salt Solutions on Phagocytosis in the Peritoneal Cavity of the Guinea-Pig

\begin{tabular}{|c|c|c|c|c|c|}
\hline \multirow{2}{*}{ Guinea-Pigs } & \multirow{2}{*}{ Salts } & \multicolumn{2}{|c|}{ M/8 Solutions } & \multicolumn{2}{|c|}{ M/300 Solutions } \\
\hline & & $\begin{array}{c}\text { Average } \\
\text { Number of } \\
\text { Cocei in Each } \\
\text { Leukocyte }\end{array}$ & $\begin{array}{l}\text { Percentage } \\
\text { of } \\
\text { Phagocytie } \\
\text { Leukocytes }\end{array}$ & $\begin{array}{l}\text { Average } \\
\text { Number of } \\
\text { Cocci in Each } \\
\text { Leukocyte }\end{array}$ & $\begin{array}{l}\text { Percentage } \\
\quad \text { of } \\
\text { Phagocytic } \\
\text { Leukocytes }\end{array}$ \\
\hline $\begin{array}{c}\text { Nonvirulent } \\
\text { Streptococci } \\
1 \\
2 \\
3 \\
4 \\
5 \\
\text { Virulent } \\
\text { Streptococci } \\
1 \\
2 \\
3 \\
4 \\
5\end{array}$ & 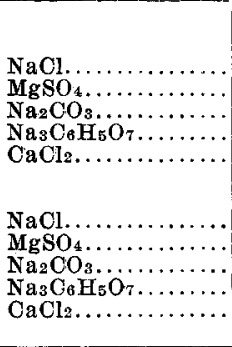 & $\begin{array}{r}12.1 \\
5.5 \\
5.1 \\
5.5 \\
4.9\end{array}$ & $\begin{array}{l}67 \\
52 \\
50 \\
48 \\
46\end{array}$ & $\begin{array}{l}17.4 \\
16.5 \\
16.1 \\
15.8 \\
17.7\end{array}$ & $\begin{array}{l}83 \\
78 \\
80 \\
81 \\
78\end{array}$ \\
\hline
\end{tabular}

TABLE 5

The Relation of Alkalinity of Blood and Phagocytosis of Streptococci in the Peritoneal Cavity

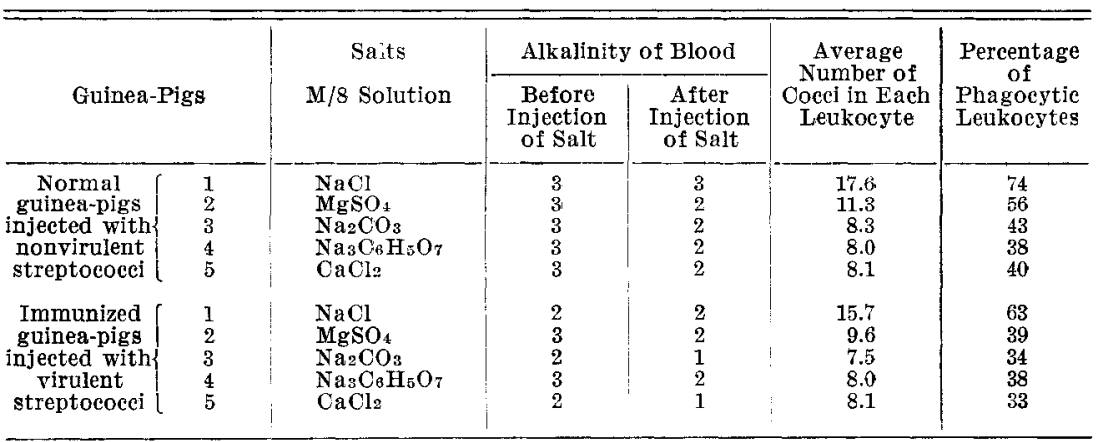

Guinea-pigs were immunized against the streptococcus by 4 intraperitoneal injections given every 5 days, consisting of 2 to $6 \mathrm{cc}$ of a 24-hour culture of streptococci in ascites broth; the culture had been heated to $60 \mathrm{C}$. for one hour. On the fourth day after the last injection, $3 \mathrm{cc}$ of salt solution were injected subcutaneously; this was repeated for 5 days (table 5 ), the results indicating that the phagocytic power of the peritoneal fluid may be decreased by the repeated injection of $\mathrm{M} / 8$ solutions of the salts used. 


\section{LANDOIS' METHOD}

Solution $A=$ Tartaric acid, $7.5 \mathrm{gm}$., dissolved in 1 liter of water. Solution $B=$ Saturated solution of sodium sulphate.

Solution A $10.0 \mathrm{cc}+$ Solution B $100.0 \mathrm{cc}=0.036 \% \mathrm{NaOH}$

Solution A $20.0 \mathrm{cc}+$ Solution B $90.0 \mathrm{cc}=0.072 \% \mathrm{NaOH}$

Solution A $30.0 \mathrm{cc}$ + Solution B $80.0 \mathrm{cc}=0.108 \% \mathrm{NaOH}$

Solution A $40.0 \mathrm{cc}+$ Solution B $70.0 \mathrm{cc}=0.144 \% \mathrm{NaOH}$

Solution A $50.0 \mathrm{cc}+$ Solution B $60.0 \mathrm{cc}=0.180 \% \mathrm{NaOH}$

Solution A $60.0 \mathrm{cc}+$ Solution B $50.0 \mathrm{cc}=0.216 \% \mathrm{NaOH}$

Solution A $70.0 \mathrm{cc}+$ Solution B $40.0 \mathrm{cc}=0.252 \% \mathrm{NaOH}$

Solution A $80.0 \mathrm{cc}+$ Solution B $30.0 \mathrm{cc}=0.288 \% \mathrm{NaOH}$

Solution A $90.0 \mathrm{cc}$ + Solution B $20.0 \mathrm{cc}=0.324 \% \mathrm{NaOH}$

Solution A $100.0 \mathrm{cc}+$ Solution B $10.0 \mathrm{c} c=0.360 \% \mathrm{NaOH}$

Levy ${ }^{9}$ ascribes the increased susceptibility of diabetes to staphylococcus infection and tuberculosis to decreased alkalescence of the blood. A diminution of opsonin in the serum of diabetics was observed by DaCosta and Beardsley. ${ }^{10}$ Other investigators have also noted that increased alkalescence of the blood may be associated with a decrease in resistance to infection. ${ }^{11} \mathrm{I}$, therefore, made some observations on the influence of certain salts on the alkalescence of the blood and phagocytic power. To determine the degree of alkalescence I used the method of Landois, the solution of the reagent being drawn up into a capillary pipet and then mixed with an equal quantity of fresh blood from the ear vein; the mixture was then tested with litmus paper. This method of testing must be continued until the particular reagent solution is found that, when mixed with blood, is neutral to litmus, the corresponding amount of alkali giving the degree of alkalinity of the blood. I made observations of this kind on normal guinea-pigs, immunized guinea-pigs and normal rabbits, and injected salt solution subcutaneously once a day for 5 days. The alkalinity of the blood was tested before the first injection and the day after the last injection, when streptococci were injected into the abdominal cavity, smears being made 3 hours later. The results are given in tables 5 and 6 . The immunized guinea-pigs received 4 intraperitoneal injections, one every 5 days, consisting of from 2 to $6 \mathrm{cc}$ of a heated 24-hour ascites broth culture of streptococci. The first injection of salt solution was given on the fourth day after the last injection of pure streptococci, the alkalinity of the blood being determined just before and the day after the injection of salt solution. In the

- Arch. f. Exper. Path. and Pharmacol., 1899, 42, p. 149.

10 Am. Jour. Med. Sc., 1908, 136, p. 361.

1t Ceni, Handb. d. Path. Mikroorg., Kolle and Wassermann, 1912, 1, p. 1001; Innocent and Zagari, ibid., p. 1004; Onodera, Nippon Naikagakukai Zasshi, 1920, 7, p. 626. 
case of the rabbits $5 \mathrm{cc}$ of salt solution were injected subcutaneously every day for 10 days. The results indicate that there may be some diminution in the alkalinity of the blood, as determined by the method used after the injection of various salts, and that at the same time there is a reduction in phagocytic power. No difference was observed in the results with normal and immunized guinea-pigs.

TABLE 6

Relation of Alkalinity of Blood to Phagocytic Activity of Rabits Injecten with Salt Solutions and Nonvirulent Streptococci

\begin{tabular}{|c|c|c|c|c|c|c|c|}
\hline \multirow{3}{*}{ Rabbits } & \multirow{3}{*}{$\begin{array}{l}\text { Salts } \\
\text { M/8 Solution }\end{array}$} & \multicolumn{2}{|c|}{$\underset{\text { Bloalinity of }}{\text { Alood }}$} & \multirow{2}{*}{\multicolumn{2}{|c|}{$\begin{array}{l}\text { Average Number of } \\
\text { Cocci in Each Leuko- } \\
\text { cyte in Mixtures Made } \\
\text { with Serum of Blood }\end{array}$}} & \multirow{3}{*}{$\begin{array}{c}\text { Average } \\
\text { Number of } \\
\text { Cocei in Each } \\
\text { Leukocyte } \\
\text { in Peri- } \\
\text { toneal } \\
\text { Fluid }\end{array}$} & \multirow{3}{*}{$\begin{array}{c}\text { Percentage } \\
\text { of } \\
\text { Phagocytic } \\
\text { Leukocytes } \\
\text { in Perito- } \\
\text { neal Fluid }\end{array}$} \\
\hline & & \multirow{2}{*}{$\begin{array}{c}\text { Before } \\
\text { Injee- } \\
\text { tion } \\
\text { of } \\
\text { Salt }\end{array}$} & \multirow{2}{*}{$\begin{array}{l}\text { After } \\
\text { Injee- } \\
\text { tion } \\
\text { of } \\
\text { Salt }\end{array}$} & & & & \\
\hline & & & & $\begin{array}{l}\text { Before } \\
\text { Injection } \\
\text { of Salt }\end{array}$ & $\begin{array}{l}\text { After } \\
\text { Injection } \\
\text { of Salt }\end{array}$ & & \\
\hline $\begin{array}{l}1 \\
2 \\
3 \\
4 \\
5\end{array}$ & $\begin{array}{l}\mathrm{NaCl} \\
\mathrm{MgSO}_{4} \\
\mathrm{Na}_{2} \mathrm{CO}_{3} \\
\mathrm{Na}_{3} \mathrm{Cl}_{6} \mathrm{H}_{5} \mathrm{O}_{7} \\
\mathrm{CaCl}_{2}\end{array}$ & $\begin{array}{l}3 \\
3 \\
4 \\
4 \\
4\end{array}$ & $\begin{array}{l}3 \\
2 \\
2 \\
2 \\
2\end{array}$ & $\begin{array}{l}13.5 \\
14.5 \\
14.0 \\
16.0 \\
15.0\end{array}$ & $\begin{array}{r}12.0 \\
7.0 \\
5.0 \\
5.0 \\
5.2\end{array}$ & $\begin{array}{l}8.9 \\
3.6 \\
2.55 \\
2.6 \\
2.7\end{array}$ & $\begin{array}{l}75 \\
35 \\
31 \\
29 \\
30\end{array}$ \\
\hline
\end{tabular}

TABLE 7

Inplugnce of Salt Solution on Chemotaxis in the Peritoneal Cavity of the Mouse

\begin{tabular}{|c|c|c|c|}
\hline Salts & M/8 Solution & M/300 Solution & $\mathbf{M} / 600$ Solution \\
\hline 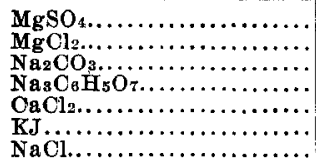 & $\begin{array}{l}16,050 \\
13,000 \\
16,300 \\
15,100 \\
13,000 \\
13,500 \\
20,500\end{array}$ & $\begin{array}{l}19,100 \\
17,700 \\
17,900 \\
18,400 \\
20,010 \\
18,700\end{array}$ & $\begin{array}{l}19,700 \\
17,200 \\
18,500 \\
22,800 \\
20.070 \\
23,100\end{array}$ \\
\hline
\end{tabular}

The flgures give the number of leukocytes in 1 c.mm.

Hamburger ${ }^{12}$ observed that a dilute solution of calcium chloride is strongly chemotactic. I made some experiments using the following method: Equal parts of salt solution and plain broth were injected into the peritoneal cavity of mice and 3 hours later the number of leukocytes in the fluid was determined (Thoma-Zeiss), the results showing that $\mathrm{M} / 8$ solutions of the salts used attracted less leukocytes than normal salt solution, this effect not obtaining with higher dilutions of the salts.

I also studied the influence of some salts on the virulence and other qualities of streptococci. For this purpose $0.5 \mathrm{cc}$ of salt

12 Biochem. Ztschr., 1910, 26, p. 66. 
solution were mixed with a quantity of streptococcus suspension just before intraperitoneal injection into mice. The salts used in this set of experiments were $\mathrm{NaCl}, \mathrm{MgSO}_{4}, \mathrm{Na}_{2} \mathrm{CO}_{3}$ and $\mathrm{Na}_{3} \mathrm{C}_{6} \mathrm{H}_{5} \mathrm{O}_{7}$, and the original streptococcus strain that had been isolated from the frontal sinus. In the case of each salt-streptococcus mixture (24hour ascites broth culture), the minimal fatal dose was determined. After the death of the mouse, cultures were made from the heart blood, and after 24 hours ascites broth was inoculated from a single colony and incubated for 24 hours, when new mixtures were made with the salt solution and a new series of mice received injections. After from 16 to 18 passages made in the manner outlined, the minimal fatal dose for mice in 72 hours of the cultures obtained from the last passage was determined with the following results:

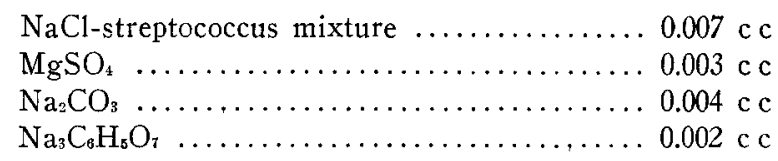

It appears that the $\mathrm{NaCl}$ strain was weakest and the $\mathrm{Na}_{3} \mathrm{C}_{6} \mathrm{H}_{5} \mathrm{O}_{7}$ strain was the strongest in virulence.

Suspensions of these salt strains of streptococci in $0.9 \% \mathrm{NaCl}$ solution were centrifugated and shaken with small glass balls to break up the chain $;^{3}$ agglutination tests were made with an antistreptococcus serum with the result that the $\mathrm{Na}_{3} \mathrm{C}_{6} \mathrm{H}_{5} \mathrm{O}_{7}$ strain agglutinated at a dilution of 1:160 only, whereas the other strains agglutinated at a dilution of $1: 640$. Phagocytosis experiments with immune serum gave similar results. For streptolysin tests streptococci were inoculated from blood agar into $10 \mathrm{cc}$ of equal parts of plain broth and ascites fluid (heated at $56 \mathrm{C}$. for 30 minutes), incubated for 18 hours and then centrifugated, the supernatant fluid being used for the test. In all cases the sterility of the medium was tested carefully before inoculation. Washed blood corpuscles from various animals were used in the test; suspensions of corpuscles and the centrifugate of the streptococcus cultures were mixed and incubated for 2 hours, the results being read after 24 hours in the icebox. It was found that even though the virulence of the streptococci had increased by passage through mice together with different salt solutions, the production of lysin showed a decrease (table 8). The fermentative power of the different salt strains of streptococci was also tested, $1 \%$ sugar broth (all the usual 
sugars) being inoculated directly from blood agar; $90 \mathrm{c} \mathrm{c}$ of distilled water was added to $10 \mathrm{cc}$ of the centrifugated broth culture 24 hours old and titrated with $\mathrm{N} / 10$ at the boiling point, phenolphthalein being indicated. While there was a slight variation in the quantity of acid produced by the different strains, no marked difference in the power of sugar fermentation was detected.

\section{SUMMARY}

Phagocytosis of streptococci in the peritoneal cavity of the mouse is diminished by $\mathrm{M} / 8$ solutions of certain salts $\left(\mathrm{MgSO}_{4}, \mathrm{MgCL}_{2}\right.$, Sr$\mathrm{Cl}_{2}, \mathrm{Na}_{2} \mathrm{CO}_{3}, \mathrm{Na}_{3} \mathrm{C}_{6} \mathrm{H}_{5} \mathrm{O}_{7}$, and $\left.\mathrm{CaCl}_{2}\right)$. $\mathrm{Ki}$ and $\mathrm{KBr}$ inhibit in lesser degree.

TABLE 8

Production of Lysin by Different Salt Stratns of Hemolytic Streptococcus

\begin{tabular}{|c|c|c|c|c|}
\hline \multirow{2}{*}{ Salt Strains of Streptococcus } & \multicolumn{4}{|c|}{ Corpuscles } \\
\hline & Mouse & Rabbits & Guirea-Pig & Sheep \\
\hline 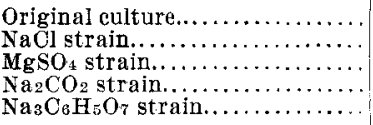 & $\begin{array}{l}0.0015 \\
0.003 \\
0.006 \\
0.006 \\
0.012\end{array}$ & $\begin{array}{l}0.003 \\
0.006 \\
0.012 \\
0.012 \\
0.025\end{array}$ & $\begin{array}{l}0.0015 \\
0.006 \\
0.012 \\
0.006 \\
0.025\end{array}$ & $\begin{array}{l}0.006 \\
0.025 \\
0.05 \\
0.05 \\
0.75\end{array}$ \\
\hline
\end{tabular}

Higher dilutions of these salts seem to have no stimulating effect on phagocytosis in vitro or in vivo. As the dilution increases the inhibitory power is lessened. Repeated injections of some of the salt solutions used appear to reduce phagocytosis in the peritoneal cavity, but no stimulating effect was obtained by subcutaneous injection of higher dilutions of the salts in question. The results were the same in normal and immunized guinea-pigs.

Each mixture contained in $1 \mathrm{c} c$ of a $5 \%$ suspension of corpuscles and $1 \mathrm{c} \mathrm{c}$ of streptococcus filtrate and salt solutions, the total quantity being always $2 \mathrm{cc}$. In the table the figures indicate the smallest quantity of streptococcus filtrates that produce definite lysis under the circumstances outlined.

Repeated subcutaneous injections of certain salts reduced the alkalinity of the blood and also the phagocytic power of the peritoneal exudate.

Fewer leukocytes appear in the peritoneal cavity 3 hours after the injection of $\mathrm{M} / 8$ solutions of $\mathrm{MgSO}_{4}$, etc., than after the injection of normal salt solution. 
When solutions of certain salts are injected together with streptococcus suspension in mice and the procedure repeated through many successive passages, some salts may have a greater influence on the character of the streptococcus than others. Thus $\mathrm{Na}_{3} \mathrm{C}_{6} \mathrm{H}_{5} \mathrm{O}_{7}$ seemed to favor the development of virulence, to reduce agglutinability and phagocytibility as well as the power to elaborate lysin, but it had no special effect on the power to ferment sugars. 